\title{
Gending Samirah Vocal by Karawitan Among Rasa Malang: Semiotics Analysis Based on Roland Barthes' Theory
}

\author{
Muhammad Ilham Isniawan ${ }^{1, *}$ Susilo Pradoko ${ }^{2}$
}

\author{
${ }^{1}$ Graduate School of Art Education, Yogyakarta State University, Yogyakarta 55281, Indonesia \\ ${ }^{2}$ Faculty of Languages and Arts, Yogyakarta State University, Yogyakarta 55281, Indonesia \\ *Corresponding author.Email: ilhamisniawan@gmail.com
}

\begin{abstract}
Gending (Javanese gamelan music) Samirah is an East Javanese repertoire that is presented in several stages. In certain areas, Gending Samirah has its own distinctive features, Gending from Lor Brantas (Surabayan area) is different from that of Kidul Brantas (Malang area) in terms of its vocals. Gending Samirah vocal from Kidul Brantas seems variative. Gending Samirah vocal Karawitan Among Rasa Malang is usually initiated with macapat (sung poetry) and then followed with songs sung by Sinden (singer singing with gamelan) and gerong (song sung in the chorus). The vocal of in Gending Samirah has its own characteristics as it usually talks about a figure and delivers messages for the continuity to preserve the local wisdom. This article aims to examine the meaning of Gending Samirah and reveal the existence of the Gending Samirah in the midst of East Java people, especially the people of Malang. This is descriptive qualitative research that employed the ethnographic method. The semiotic approach was employed to analyze the meaning of lyrics in Gending Samirah, then the results were used to describe the denotative, connotative, and mythical meanings of the lyrics.
\end{abstract}

Keywords: Vocal, Gending Samirah, karawitan Among Rasa Malang, Semiotics, Roland Barthez

\section{INTRODUCTION}

Gending is the result of composing notes based on the Pathet rules, forms and patterns of gamelan. Gending takes many forms in shows, for example, repertoire (uyon-uyon), beksan (dance) accompaniment and shadow puppet music accompaniment. Uyon-uyon is a collection of several repertoires played based on the player's creativity. Gending played in shadow puppet show is based on scenes or fragments, situation, and puppet movements. Gending played at the beginning of a show delivers the meaning of inviting so that the sound is loud. Gending Soran usually only presents instrumental plays, for example in the form of ladrang, giro and lancaran, but in other repertoire there are also vocals with various variations.

Music developing outside the palace has various characteristics, although it is a form of creativity based on the culture of a particular area. These characteristics can be viewed from several elements such as instrument organology, vocal work, and special patterns, for example in Gending Samirah. This type of Gending develops in East Java, and is used to accompany various performances, for example dances, puppets shows, and other traditional art performances (ludruk). Gending Samirah in several events presents its own style, for example when shown in shadow puppet shows, tayub, and uyon-uyon.

Gending Samirah in certain areas, for example in the Lor Brantas (Surabayan area) is performed in a different way from the way it is performed in Kidul Brantas (Malang area). This difference can be felt in the lyric and Ricikan Balungan pattern, but the elements of Babonan Gending (basic balungan) generally still have similarities. The vocal in Gending Samirah in the Kidul Brantas seems to have more Sinden and Gerong variations than in Lor Brantas. The addition of vocal in Gending Samirah is usually shown in uyon-uyon performed by Among Rasa Malang musical group. The renewal of the vocals and the patterns of the Samirah musical composition by the musical group Among Rasa Malang, create special characteristics that made it different from other Samirah repertoires. Gending Samirah performed by Among Rasa Malang is 
interesting to be examine in research. Thus, researchers try to focus on how vocal/lyric is presented and what the meaning and functions of the gending are. The characteristics especially those related to Gending Samirah Among Rasa Malang and other gendings are further explained in this study.

Gending Samirah Karawitan Among Rasa Malang was first presented for the needs of Klenengan (initiating a shadow puppet show). The presentation of Gending Samirah shows varies because it consists of a series that are intertwined. The first part consists of macapat song which has become a typical Malang icon, then it continues with the Samirah gending performing its sindenan and gerong. The sequence was purely composed by the composer Karawitan Among Rasa Malang (Alm. Ki Sumantri). He was the creator of the vocal elements in the Gending Samirah. The composition of Gending Samirah is bound by the tone of the gong, thus creating a connection in the presentation of the Gending (padang ulihan/song sentences). Vocals are the main element in the work of the Gending Samirah, Among Rasa karawitan group, so that it becomes dominant in the repertoire of Gending Samirah in other places.

This is a qualitative study employing ethnographic methods using the semiotic approach by Roland Barthes. This approach was used because the researcher intends to interpret, study, and understand the reasons why late Ki Sumantri, the composer of the musical group Among Rasa created Gending Samirah Vocal. The vocals in the Gending Samirah Among Rasa Malang consist of macapat, sindenan and gerongan songs, each of which has a different meaning. The vocal is translated in the form of cakepan text (lyrics) in which its' linguistic component can be studied with semiotic theory. Semiotics is a method of signification on linguistic objects, texts, non-texts which are related to the signs. According to Barthes, semiotics has several elements, namely denotative, connotative and mythical meanings. Denotative, is the first meaning, revealing the literal meaning of a text. Connotative reveals a deeper meaning, presenting another point of view based on an object. Then, myth is the third stage of signification according to Roland Barthes. It is the delivery of a message based on signs. Myth according to Barthes is the meaning of signs based on facts or reality. The connotative meanings that have been formed in society develop into myths. This study was focused on how the presentation of the vocal (lyric) in Gending Samirah Karawitan Among Rasa Malang is and what the meanings of the vocal Gending Samirah by Karawitan Among Rasa Malang according to Roland Barthes' semiotic theory are.

\section{RESEARCH METHOD}

This is a qualitative study employing ethnographic methods using the semiotic approach by Roland Barthes. This approach was used because the researcher intends to interpret, study, and understand the reasons why late Ki Sumantri as the composer of the musical group Among Rasa created the Gending Samirah Vocal. According to Barthes, semiotics is a study on signs including movement, gesture, sound, and phenomena in a reality. Roland Barthes explained that semiotics tries to explain the meaning, motive and nature of a sign or event. Barthes added that a sign or event keeps inspiration and has a relationship with other signs so that it can be understood as a whole.

The research subject was a composer of the Karawitan group Among Rasa Malang. Data sources were divided into two, namely primary data and secondary data. The primary data were collected through interviews, while the secondary data were collected through surveys and documentation. The collected data were then analyzed and went through data reduction, data presentation, and conclusion drawing. Meanwhile, the validity test of the data employed triangulation techniques done by cross-validating the data collected from the interviews, observation, and documentation.

\section{RESULTS AND DISCUSSION}

The lyric in Gending Samirah by Karawitan Among Rasa Malang consists of a set of macapat (poetry) of Sinom Malangan, and then followed by Gending Samirah, sindenan, and gerong. Below is the lyric of vocal in Gending Samirah.

\subsection{Vocal (Lyric) of Gending Samirah Karawitan Among Rasa Malang}

1. Macapat Sinom Malangan

Prawane wong lowokdoro

Iseh cilik njaluk rabi

Sun adang nok mergosono

Kutha lawas den baleni

Jodipan kang winarni

Tumenggungan dalemipun

Klojen lan kayutangan

Kauman den isen-isen

Wes gumelun wes gumelun

Wes gumelun candhekan ugal-ugalan 


\section{Sindenan}

Ingsun miwiti tembang lan kidung

Iku minangka bukaning gending

Jawa wetan sing adiluhung

Mugo lestari klawan ngrembaka

3. Gerongan I Gending Samirah

Ana crita rikala jaman semana

Pahlawan buruh saka suku Madura

Pendalungan pak sakerah ingkang nama

Mungsuh landa mbela nasibe kawula

Tantrimana ana astane sing Kwasa

Ono konco dadi sroyo wong walanda

Gending samirah iku sing dadi marga

Nganti tega ngorbano jiwa lan raga

4. Gerongan II Gending Samirah

Pawelinge bapa biyung

Wong priya ngopeni garwa klawan putra

Ngestiti lan ati-ati

Garwanira abote marang kang putra

Mula kita aja laku sulaya

Tindakna kang utama mring sapadha-padha

Supaya dadi tuladha

\subsection{Roland Barthes's Semiotics Analysis}

Gending samirah karawitan Among Rasa Malang is one of the East Javanese repertoire pieces from Malang area. Gending Samirah is usually played in shadow puppet show events as its vocal is not dominant. The lyric in the sindenan resembles Yogyakartan or Surakartan styles as it sounds polite. The language style of East Javanese Gending is more tough and direct, in accordance with the culture in society. Gending Samirah karawitan Among Rasa Malang has vocals that adopt and adapt to the East Javanese "bloko". The sindenan is in the form of parikan (not wangsalan) showing that it belongs to Javanese literature, with its East Javanese language.

Gending samirah has developed for pure musical needs (uyon-uyon) which is closely related to vocals and instrumental creativity. Gending Samirah karawitan Among Rasa Malang in certain conditions is a pedanyangan gending, or a piece dedicated to an ancestor or elders who passed away and guarded (mbahureksa) a certain area. This information is obtained based on the transcendental (mental) mechanisms that underlie the idea of composing Gending Samirah to be more varied in terms of vocals and instrumentals.

The vocal in Gending Samirah Among Rasa conveys meaning. In this study, the lyric is analyzed using Roland Barthes' semiotic theory to reveal its' denotative, connotative and mythical elements. The following tables are the results of meaning analysis.

Table 1. The meanings of Macapat Sinom Malangan analyzed using Roland Barthes' Semiotics Theory

\begin{tabular}{|l|l|l|l|}
\hline Macapat: & Denotative Meaning & Connotative Meaning & Myth \\
\hline $\begin{array}{l}\text { Prawane wong lowokdoro, } \\
\text { Iseh cilik njaluk rabi }\end{array}$ & $\begin{array}{l}\text { A girl from Lowokdoro } \\
\text { village is a teenager, but she } \\
\text { wants to be married off } \\
\text { immediately. }\end{array}$ & $\begin{array}{l}\text { Early marriage problems are } \\
\text { caused by various factors. }\end{array}$ & $\begin{array}{l}\text { Marriage needs maturity to } \\
\text { create a harmonious family. }\end{array}$ \\
\hline $\begin{array}{l}\text { Sun adang nok mergosono, } \\
\text { Kutha lawas den baleni }\end{array}$ & $\begin{array}{l}\text { I cook rice (adang) in } \\
\text { Mergosono, the old town on } \\
\text { repeat. }\end{array}$ & $\begin{array}{l}\text { Showing the name of an area, } \\
\text { namely Mergosono, the old } \\
\text { town and kebalen }\end{array}$ & $\begin{array}{l}\text { Kebalen is the name of a } \\
\text { market located in the old } \\
\text { town of Malang. }\end{array}$ \\
\hline $\begin{array}{l}\text { Jodipan kang winarni } \\
\text { Tumenggungan dalemipun }\end{array}$ & $\begin{array}{l}\text { A colorful jodipan, his house } \\
\text { is in Tumenggungan. }\end{array}$ & $\begin{array}{l}\text { Jodipan is famous as a } \\
\text { colorful village and a tourist } \\
\text { spot. }\end{array}$ & $\begin{array}{l}\text { Malang is a city famous of its } \\
\text { tourism sector (Jodipan, } \\
\text { Sengkaling, Balekambang } \\
\text { beach). }\end{array}$ \\
\hline Klojen lan kayutangan & $\begin{array}{l}\text { Klojen and Kayutangan, } \\
\text { Kauman and Kasin }\end{array}$ & $\begin{array}{l}\text { Mentioning the names of } \\
\text { popular places in Malang } \\
\text { Klojen and Kayutangan, } \\
\text { Kauman and Kasin }\end{array}$ & $\begin{array}{l}\text { A historical place in the city } \\
\text { of Malang, there are Dutch } \\
\text { heritage buildings in } \\
\text { Kayutangan }\end{array}$ \\
\hline
\end{tabular}


Table 2. The analysis of Sindenan meanings based on Roland Barthes's Semiotics Theory

\begin{tabular}{|l|l|l|l|}
\hline $\begin{array}{l}\text { Sindenan: } \\
\begin{array}{l}\text { Ingsun miwiti tembang lan } \\
\text { kidung, } \\
\text { Iku minangka bukaning } \\
\text { gending }\end{array}\end{array}$ & $\begin{array}{l}\text { I started nembang (chanting) } \\
\text { and kidung, that includes } \\
\text { bukaning gending }\end{array}$ & $\begin{array}{l}\text { Songs and chant can be used } \\
\text { to start a music, for example, } \\
\text { in a macapat song }\end{array}$ & $\begin{array}{l}\text { The first step to start } \\
\text { something is with target and } \\
\text { prayer. Then, people may } \\
\text { continue working. It is like } \\
\text { how Gending is played. }\end{array}$ \\
$\begin{array}{l}\text { Jawa wetan sing adiluhung, } \\
\text { Mgrembaka }\end{array}$ & $\begin{array}{l}\text { Honorable East Java, } \\
\text { hopefully it will remain } \\
\text { known and sustainable }\end{array}$ & $\begin{array}{l}\text { East Java has a distinctive } \\
\text { local culture and arts that } \\
\text { need to be preserved }\end{array}$ & $\begin{array}{l}\text { Each region has its own form } \\
\text { of local wisdom, which } \\
\text { makes a nation diverse, } \\
\text { united in Unity in Diversity }\end{array}$ \\
\hline
\end{tabular}

Table 3. The analysis of Gerongan I meanings based on Roland Barthes's Semiotics Theory

\begin{tabular}{|c|c|c|c|}
\hline Gerongan I: & Denotative Meaning & Connotative Meaning & Myth \\
\hline $\begin{array}{l}\text { Ana crita rikala jaman } \\
\text { semana, } \\
\text { Pahlawan buruh saka suku } \\
\text { Madura, } \\
\text { Pendalungan pak sakerah } \\
\text { ingkang nama, } \\
\text { Mungsuh landa mbela nasibe } \\
\text { kawula, } \\
\text { Tantrimana ana astane sing } \\
\text { Kwasa, } \\
\text { Ono konco dadi sroyo wong } \\
\text { walanda, } \\
\text { Gending samirah iku sing } \\
\text { dadi marga, } \\
\text { Nganti tega ngorbano jiwa } \\
\text { lan raga }\end{array}$ & $\begin{array}{l}\text { Once upon a time, there was } \\
\text { a story of a hero from the } \\
\text { Madurese tribe named Pak } \\
\text { Sakera. He defended the } \\
\text { workers from Dutch } \\
\text { oppression, risked his life and } \\
\text { God' destiny. He is a hero } \\
\text { who gave up his whole body } \\
\text { and soul even to be betrayed } \\
\text { by his friends. }\end{array}$ & $\begin{array}{l}\text { - Gending samirah tells the } \\
\text { history Mr. Sakera } \\
\text { heroism, } \\
\text { - Gending samirah is the } \\
\text { path of a hero, Mr. Sakera, } \\
\text { in scarifying his body and } \\
\text { soul }\end{array}$ & $\begin{array}{l}\text { - Kindness and fairness } \\
\text { require sacrifice and even } \\
\text { life can be at stake } \\
\text { - The Madurese tradition of } \\
\text { migrating } \\
\text { - When someone is kind, he } \\
\text { will always be } \\
\text { remembered. Javanese } \\
\text { proverb "gajah mati } \\
\text { ninggal gading, macan } \\
\text { mati ninggal walulang", }\end{array}$ \\
\hline
\end{tabular}

Table 4. The analysis of Gerongan II meanings based on Roland Barthes's Semiotics Theory

\begin{tabular}{|c|c|c|c|}
\hline Gerongan II & Denotative Meaning & Connotative Meaning & Myth \\
\hline $\begin{array}{l}\text { Pawelinge bapa biyung } \\
\text { Wong priya ngopeni garwa } \\
\text { klawan putra } \\
\text { Ngestiti lan ati-ati } \\
\text { Garwanira abote marang } \\
\text { kang putra } \\
\text { Mula kita aja laku sulaya } \\
\text { Tindakna kang utama mring } \\
\text { sapadha-padha } \\
\text { Supaya dadi tuladha }\end{array}$ & $\begin{array}{l}\text { It contains a reminder from } \\
\text { father and mother to a man to } \\
\text { take care of his wife and } \\
\text { children, be cautious. } \\
\text { A wife should prioritize her } \\
\text { children, be kind to others, so } \\
\text { she can be a role model for } \\
\text { her family. }\end{array}$ & $\begin{array}{l}\text { - Listening to parents' } \\
\text { advice } \\
\text { - } \text { Be cautious } \\
\text { - Always maintain a } \\
\text { positive attitude, be an } \\
\text { example for generations }\end{array}$ & $\begin{array}{l}\text { - Being conscientious and } \\
\text { careful is the key in all } \\
\text { aspects of life } \\
\text { - Ethics and behavior make } \\
\text { a person. }\end{array}$ \\
\hline
\end{tabular}




\section{CONCLUSION}

Gending Samirah Karawitan Among Rasa has a variation of lyric and balungan pattern that makes it different from Gending Samirah from other areas. Vocal in this Gending Samirah reflects the society language style. It consists of sinom Malangan, parikan in the form of Sindenan and Gerongan. Gending Samirah is performed in events, such as shadow puppet shows.

Gending Samirah Karawitan Among Rasa Malang was analyzed using Roland Barthes' semiotics theory. The result is presented below.

1. Macapat sinom Malangan. The lyric tells about some places known as the icon of Malang city which has both educational and historical values.

2. Sindenan. It tells the need to preserve the local wisdom of an area.

3. Gerongan I. This part tells the history of a figure, called Mr. Sakera. The message is about the character or moral values based on the story.

4. Gerongan II. This part contains aspects of education, family, being ethical, and showing good attitudes in interacting with society.

\section{REFERENCES}

[1] Barthez, Roland. Mythologies, tr. Annette lavers, New York: The Noonday Press (1991).

[2] Purwadi. Upacara Tradisional Jawa [Javanese Traditional Ceremony. Yogyakarta: Pustaka Pelajar, 2005.

[3] Sulistiyono, Singgih Tri. Multikulturalisme dalam Perspektif Budaya Pesisir [Multiculturalism in a Coastal Cultural Perspective]. Agastya 5(1), 2015. pp. 1-18. DOI: doi.org/10.25273/ajsp.v5i01.893

[4] Haryono, Timbul. Estetika Bawa dalam Karawitan Gaya Surakarta [Bawa aesthetics in the Karawitan Style of Surakarta]. Resital: Jurnal Seni Pertunjukan (Journal of Performing Arts) 16(1), 2015. pp. 36-51. DOI: doi.org/10.24821/resital.v16i1.1273

[5] Sukesi, Sukesi. Musikalitas Karawitan Jawatimuran [East Javanese Karawitan Musicality]. Jurnal Lakon 7(1), 2010. pp. 85-107. URL: http://repository.isi-ska.ac.id/2320/

[6] Wibawa, Sutrisna. Filsafat Jawa [Javanese Philosophy]. Yogyakarta: UNY Press, 2013. 